\title{
DÜBLIN
}

Technological University Dublin

ARROW@TU Dublin

2010-05-20

\section{Rainwater Harvesting and Greywater Treatment Systems for Domestic Application in Ireland}

\author{
Zhe Li \\ Technological University Dublin, zhe.li@tudublin.ie \\ Fergal Boyle \\ Technological University Dublin, fergal.boyle@tudublin.ie \\ Anthony Reynolds \\ Technological University Dublin, anthony.reynolds@tudublin.ie
}

Follow this and additional works at: https://arrow.tudublin.ie/engschmecart

Part of the Education Commons, and the Engineering Commons

\section{Recommended Citation}

$\mathrm{Li}, \mathrm{Z}$.: Rainwater harvesting and greywater treatment systems for domestic application in Ireland.

Desalination. Volume 260, Issues 1-3, Pages 1-8. 30 September 2010. doi:10.1016/j.desal.2010.05.035

This Article is brought to you for free and open access by the School of Mechanical and Design Engineering at ARROW@TU Dublin. It has been accepted for inclusion in Articles by an authorized administrator of ARROW@TU Dublin. For more information, please contact arrow.admin@tudublin.ie, aisling.coyne@tudublin.ie, gerard.connolly@tudublin.ie.

Funder: Irish Research Council for Science, Engineering \& Technology

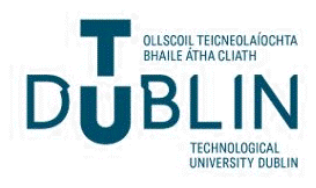




\title{
Rainwater harvesting and greywater treatment systems for domestic application in Ireland
}

\author{
Zhe $\mathrm{Li}^{*}$, Fergal Boyle, Anthony Reynolds \\ Department of Mechanical Engineering, Dublin Institute of Technology, Bolton Street, Dublin 1, Ireland
}

\section{A R T I C L E I N F O}

\section{Article history:}

Received 5 March 2010

Received in revised form 19 May 2010

Accepted 20 May 2010

Available online 12 June 2010

\section{Keywords:}

Rainwater harvesting

Greywater treatment

Sustainable living

Domestic water supply

Ireland

\begin{abstract}
A B S T R A C T
Water shortage has been recognised as one of the key issues facing many countries. Fortunately, there are relatively abundant water resources available in Ireland because of its plenty of rainfall. However, Ireland will inevitably encounter water shortage in the future, especially in urban areas. The water consumption per capita per day in Ireland is one of the highest in Europe. The water demand is still increasing due to population growth and higher standard of living. The use of domestic rainwater harvesting and greywater treatment systems has the potential to supply nearly $94 \%$ of domestic water in Irish households. The utilisation of these systems can help Irish householders achieve significant water savings and avoid the domestic water bills that are due to be reintroduced. It also helps take pressure of the centralised water supply to meet the increasing water demand in Ireland and eliminates issues such as high leakage during delivery and large treatment costs for domestic utilisation. Domestic rainwater harvesting and greywater treatment systems can play a very important role in future water management and prospective sustainable living in Ireland.
\end{abstract}

(c) 2010 Elsevier B.V. All rights reserved.

\section{Contents}

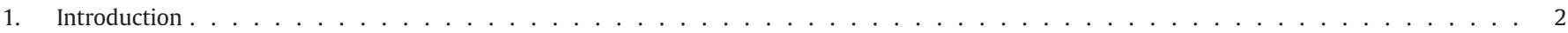

2. The current domestic water situation in Ireland . . . . . . . . . . . . . . . . . . . . . . . . . . . . . . . . 2

2.1. Current domestic water consumption. . . . . . . . . . . . . . . . . . . . . . . . . . . . . . . . 2

2.2. Current issues in domestic water supply . . . . . . . . . . . . . . . . . . . . . . . . . . . . . 2

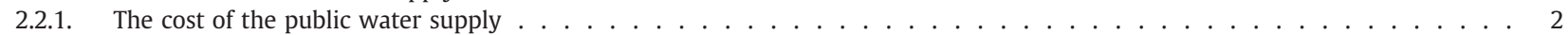

2.2.2. Water leakage in the distribution system. . . . . . . . . . . . . . . . . . . . . . 2

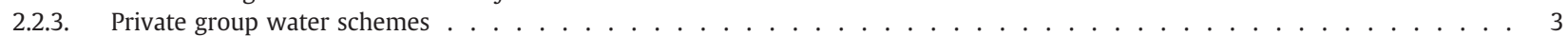

3. The key drivers for applying domestic water systems in Ireland. . . . . . . . . . . . . . . . . . . . . . . . . . 3

3.1. Domestic water charges . . . . . . . . . . . . . . . . . . . . . . . . . . . . . 3

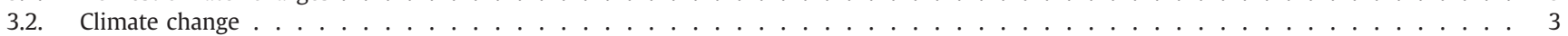

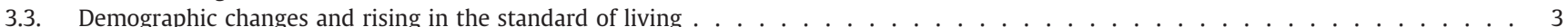

3.4. The quality of water for non-potable use . . . . . . . . . . . . . . . . . . . . . . . . . . .

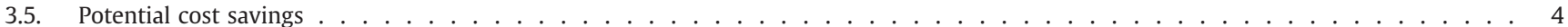

4. Domestic rainwater harvesting and greywater treatment systems . . . . . . . . . . . . . . . . . . . . . . . . . . 4

4.1. Domestic rainwater harvesting system . . . . . . . . . . . . . . . . . . . . . . . . . . . 4

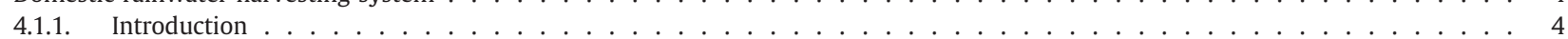

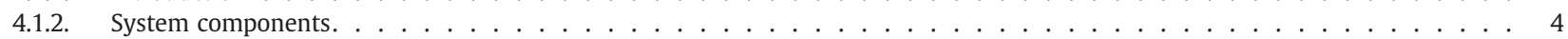

4.1.3. Domestic harvested rainwater quality . . . . . . . . . . . . . . . . . . . . . . . . 5

4.1.4. Treatment of domestic harvested rainwater . . . . . . . . . . . . . . . . . . . . . . . . . . 5

4.1.5. Benefits of a domestic rainwater harvesting system . . . . . . . . . . . . . . . . . . . . . . . . . . 6

4.1.6. Cost of a domestic rainwater harvesting system . . . . . . . . . . . . . . . . . . . . . . . . . . . . . . . 6

4.2. Domestic greywater treatment system . . . . . . . . . . . . . . . . . . . . . . . . . . 6

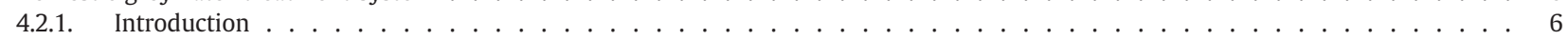

4.2.2. Characteristic of greywater . . . . . . . . . . . . . . . . . . . . . . . . . . . . . . . . 6

\footnotetext{
* Corresponding author. Tel.: + 35314022991

E-mail address: zhe.li@dit.ie (Z. Li).
} 
4.2.3. Greywater treatment technologies . . . . . . . . . . . . . . . . . . . . . . . . . . . . . . . . . . 6

4.2.4. Costs of a domestic greywater treatment system . . . . . . . . . . . . . . . . . . . . . . . . . . . . . . . . . . . 7

5. Potential water savings by using domestic water systems in Irish homes. . . . . . . . . . . . . . . . . . . . . . . . . . . . . . . . . . 7

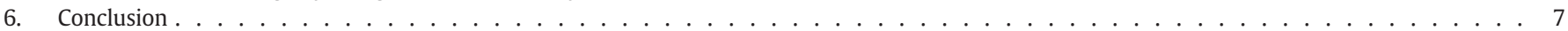

Acknowledgement. . . . . . . . . . . . . . . . . . . . . . . . . . . . . . . . . . . . . . 7

References . . . . . . . . . . . . . . . . . . . . . . . . . . . . . . . . . . 7

\section{Introduction}

Water shortage is becoming the largest problem in the world today. Freshwater resources have been increasingly polluted and depleted globally. This is constantly threatening sustainable development, and human and ecosystem health [1]. The water supply can hardly keep pace with demand nowadays. The global demand for water has doubled roughly every 21 years.

Ireland has an abundance of water resources because of its high rainfall levels. However, water shortage will be one of key issues that Ireland has to envisage in the very near future, especially in the greater Dublin region. Water demand has been constantly increasing due to the population growth, higher standard of living and climate change, with the result that water shortage is expected to occur in Ireland in the next 10 years or even before [2]. Providing sufficient and adequate water for the estimated 5 million people in Ireland by 2021 is going to be a major task for the Department of the Environment, Heritage and Local Government. The quality of water in many Irish water resources (e.g. lakes, rivers and water reservoirs) has deteriorated in recent decades due to climate change and human activities. Large costs and high leakage levels are amongst the key issues in the public centralised water treatment and water delivery in Ireland.

The use of domestic rainwater harvesting (DRWH) and greywater (GW) treatment systems can significantly lessen demand from the public water supply. These systems can be part of the solution for tackling water shortage in Ireland, and can be an important part of Ireland's sustainable development. The benefits from an economic point of view are for both the country and householders. In particularly, the future introduction of a domestic water supply and a wastewater treatment charge could make these water systems even more attractive for householders. This paper outlines the current water supply issues in Ireland, the key drivers for applying DRWH and GW treatment systems, and the currently available systems.

There is an onus on the government to improve the understanding of the social impact, the potential, and the performance of domestic water systems in Ireland. Information should be provided from public water sector to help householders accept domestic water systems. This information could also assist householders to assess the systems' costs and benefits. Domestic water systems can both provide a source of water and can involve the public in water management, thus making householders more aware of water conservation and recycling.

\section{The current domestic water situation in Ireland}

The current domestic water situation in Ireland can best be described from two aspects: current domestic water consumption and current issues in domestic water supply.

\subsection{Current domestic water consumption}

The water supplied to the residential sector is a significant portion of total publicly-supplied water in Ireland. In 2006, domestic usage accounted for approximately $60 \%$ of the total water demand [3]. Agriculture, commercial and industrial consumption accounted for the remaining $40 \%$. Ireland's domestic water consumption per capita per day is one of the highest in Europe. Domestic water consumption per capita per day in selected EU countries is shown in Fig. 1.

The water consumption per capita per day increased from 130 l1391 in 1997 to 1481 in 2006 in Ireland [3]. Along with population growth and climate change, the rise in the standard of living is one of the main factors for the increased domestic water consumption, especially for personal hygiene. In a typical house, the volume of water used for toilet flushing, showering and bathing, and in washing machines and dishwashers is much greater than the volume of water used for drinking and cooking. The breakdown of domestic water consumption per capita per day in an average household in Ireland in 2006 is shown in Fig. 2.

\subsection{Current issues in domestic water supply}

The cost of the public water supply, water leakage in the distribution system, and private group water schemes are the main current issues in domestic water supply.

\subsubsection{The cost of the public water supply}

Around $80 \%$ of the population-receiving water supply is from surface abstraction (rivers and lakes and reservoirs) in Ireland [3]. Groundwater and spring-supply water account for $18 \%$ and $2 \%$ respectively. As a result of climate change and human activities, surface water has been extensively contaminated and polluted and its quality is not adequate for domestic use. Water must be treated to a high standard in order to make it fit for human consumption. There were 869 water and sewage schemes invested in between 2004 and 2006 across Ireland with a total cost of approximately $€ 5$ billion $[5,6]$. The costs involved in constructing treatment plants, processing water and delivering water to households are substantial. The annual cost of the public water supply has to be raised through general taxation, even though the water is free for domestic householders in Ireland. Table 1 shows the annual costs for water supply in Ireland in 2006.

\subsubsection{Water leakage in the distribution system}

The level of water leakage during delivery is high in Ireland in comparison with other EU countries. According to a recent study, a typical EU country has a water leakage of around $30 \%$ of total water

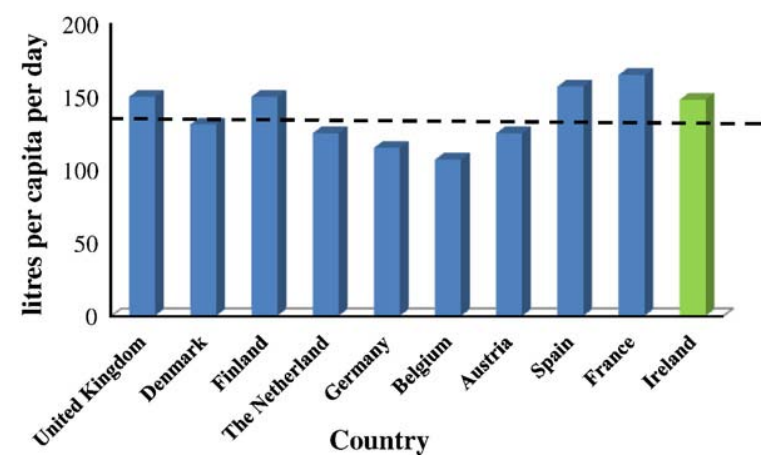

Fig. 1. Average domestic water consumption per capita per day in selected EU countries in 2006 [4]. 


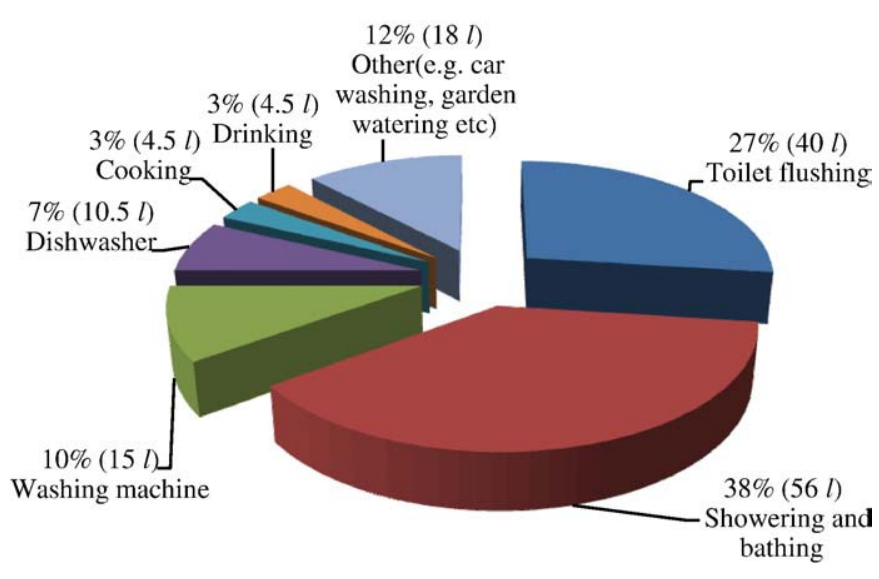

Fig. 2. Breakdown of domestic water consumption per capita per day into various uses in Ireland in 2006 [3].

supply [8]. The overall water loss during distribution was in excess of $40 \%$ in the Dublin region in the late 1990 s, but was reduced to $30 \%$ by 2008 [2]. This was achieved by large expenditure on pro-active leakage management and substantial network rehabilitation schemes. Over the last seven years, €140 million was spent on monitoring water use and losses throughout the supply network, fixing leaks and replacing defective pipes in Ireland [9]. However, leakage still accounts for as much as $45 \%$ of the water supply in the distribution systems in some urban areas [10]. This corresponds to 601 to 1001 of water production losses per capita per day in Ireland. These massive water losses from leakage result in wasted expenditure on unnecessary water treatment, leakage management and water network rehabilitation. The estimated wasted expenditure is approximately $€ 120$ million between 2007 and 2011 alone [2].

\subsubsection{Private group water schemes}

Water is supplied by private group water schemes if households are not connected to the public water supply in Ireland. There are 588 private group water schemes currently running in Ireland [11]. These schemes are formed by a number of households coming together to provide their own water supply. The water supplies are either from the public (if available) or a private source (well or lake, etc). However, water has to be paid for if the household belongs to a private group water scheme. Water quality has been seen as the main concern for private group water supply. According to national reports on the quality of drinking water in Ireland, the poorly treated or untreated private group water supplies are most at risk from pollution [12]. The local government does not have any input into the running of group schemes as they are not responsible for maintaining group scheme pipes and filtration systems.

\section{The key drivers for applying domestic water systems in Ireland}

The key drivers show the necessity and urgency for applying domestic water systems in Ireland. These systems will help Ireland establish a sustainable water policy and prevent water shortages.

Table 1

The annual costs for the public water supply in Ireland in 2006 [7].

\begin{tabular}{ll}
\hline Category & Billions of Euros \\
\hline Capital costs & 0.678 \\
Operation costs & 0.638 \\
Total costs & 1.316 \\
Payments by industry and other non-domestic sectors & 0.133 \\
Net annual costs & 1.183 \\
\hline
\end{tabular}

\subsection{Domestic water charges}

The domestic water charge in urban areas was abolished in Ireland in 1997 [13]. However following serious concerns about water shortage and the recent financial crisis, the domestic water charge is expected to be reintroduced by the Irish government as soon as 2010 [13]. However, generally there are no water meters installed in domestic houses and, as a result, the water cannot be charged with volumetric measures. A flat water charge of around $€ 200$ per household per year is the preferred solution from the Irish government until water meters are installed [14]. It is planned to install water meters for the whole 1.1 million houses that are connected to the public water mains across Ireland over a two-year period. The potential water charge could have a large financial impact on Irish householders and, in particular, low-income families. The future cost of water per household is not known yet in Ireland. However, the UK water cost per household can be taken as a valuable example, as the average water consumption per capita per day is comparable and the cost of living is similar between Ireland and UK. The water bill for an average household with three occupants is between $£ 170$ and $£ 300$ per year in the UK [15]. Apart from the domestic water supply charge, wastewater treatment is also charged in the UK and depends on the amount of wastewater released for public water treatment. The wastewater charge is about $£ 130$ to $£ 300$ a year for a domestic house and this could also be introduced in Ireland. The current price of water per $\mathrm{m}^{3}$ will be expected to rise because of the increasing water demand. Irish householders may be facing similar water bills as their UK counterparts.

\subsection{Climate change}

The alteration of Ireland's climate due to the effects of climate change is not fully known. The rainfall patterns will likely vary in an unexpected manner [16]. Climate change is also expected to lead to hotter and dryer summer months and wetter winter months. Climate change may also alter the groundwater regime, and thus the $18 \%$ of ground-source-supplied water is at the risk of being affected in Ireland [3]. Finding new water sources and developing new technologies to produce water in large scale are crucial to meet the increasing public water demand.

\subsection{Demographic changes and rising in the standard of living}

Population growth has been recognised as one of the most important factors in increasing water demand in Ireland. The population is expected to increase from the current 4.5 million to an estimated 5 million by 2021 in Ireland [17]. Even though the majority of these new households are likely to be small, that could be less than the current 2.8 person per household in Ireland [18]. The growing number of household and rising in the standard of living will raise the overall water demand as a result of increasing use of washing machines, showers, toilets and gardens, etc.

\subsection{The quality of water for non-potable use}

Using 2006 figures, only 6\% of domestic water supply is used for drinking and cooking purposes [3]. The rest of the water supply does not have to reach drinking quality. However, domestic water is generally not supplied through separate pipes for different utilisation. The high-quality treated water is unnecessarily used for low-qualityrequired appliances. It is not energy efficient and economical to use high-quality water for these appliances as they only require lowquality water. As Ireland has very little indigenous fuel resources, the majority of energy produced is from imported fossil fuels [19]. Energy saving is therefore very important for the country's sustainable 
development. The impact of the current recession also means Ireland must try to avoid any unnecessary expenditure.

\subsection{Potential cost savings}

The widespread implementation of DRWH and GW treatment systems will help reduce and control surface runoff in Ireland. It should result in a reduced need for additional water treatment facilities and supply infrastructure to cope with the increasing water demand and therefore lower Ireland's total costs for water supply. The costs for wastewater handling can be also lowered by decreasing wastewater input for treatment plants, thus reducing the need to upgrade wastewater treatment works in the future.

\section{Domestic rainwater harvesting and greywater treatment systems}

The utilisation of domestic water systems can ensure a long-term supply of water with adequate quality for household water appliances while minimising adverse economic, social and ecological impacts. Hence, the utilisation of these systems will enable Ireland to achieve sustainability in water supply.

\subsection{Domestic rainwater harvesting system}

\subsubsection{Introduction}

Harvested rainwater is a renewable clean water source that is ideal for domestic uses. The harvested water is mainly used for non-potable purposes such as toilet flushing, laundry, car washing and garden watering. However, the harvested rainwater is also drinkable if specific treatments are taken. The use of DRWH systems can lead to significant domestic water savings worldwide. According to international studies on houses that have installed DRWH systems, a reduction of between $30 \%$ and $92 \%$ in the volume of publicly-supplied can be achieved [20]. The unique climate in Ireland ensures there is plenty of rainfall throughout the year. The average annual number of wet days (days with more than $1 \mathrm{~mm}$ of rain) along the east and south-east coasts is about 150 and about 225 in parts of the west [21]. The majority of the eastern half of the country has between 750 and $1000 \mathrm{~mm}$ of rainfall annually, while the rainfall generally averages between 1000 and $1250 \mathrm{~mm}$ in the west. Many of the mountainous districts have rainfall exceeding $2000 \mathrm{~mm}$ per year [21]. In Ireland, rooftop rainwater harvesting is the most commonly used technology, as roofs represent a large percentage of the urban impermeable areas and are ideal for rainwater harvesting. Harvested water is generally less contaminated using roofs as catchments compared with other catchment types (e.g. land surface, road surface, and rock catchments). A typical rooftop rainwater harvesting system in Ireland is shown in Fig. 3.

\subsubsection{System components}

Typically, a DRWH system consists of three components: a catchment, a runoff delivery system and a storage tank.

- The catchment - the catchment has to be impermeable and cannot seriously contaminate the rainwater. Roofs of houses are the most common type of catchment used for harvesting water on a domestic scale in Ireland. The material used in constructing the roof and the effective roof area have a major influence on the efficiency of collection and the water quality [20]. Smooth, clean and imperious materials are preferable, such as galvanised, corrugate-iron sheets, corrugated plastic and tiles, which all make good roof catchment surfaces. Flat cement or felt-covered roofs can also be used provided they are clean [22]. These have good durability, are low-cost, and provide reasonable quality water. A non-toxic painted or coated roof can be used for rainwater harvesting. However, it has to be used

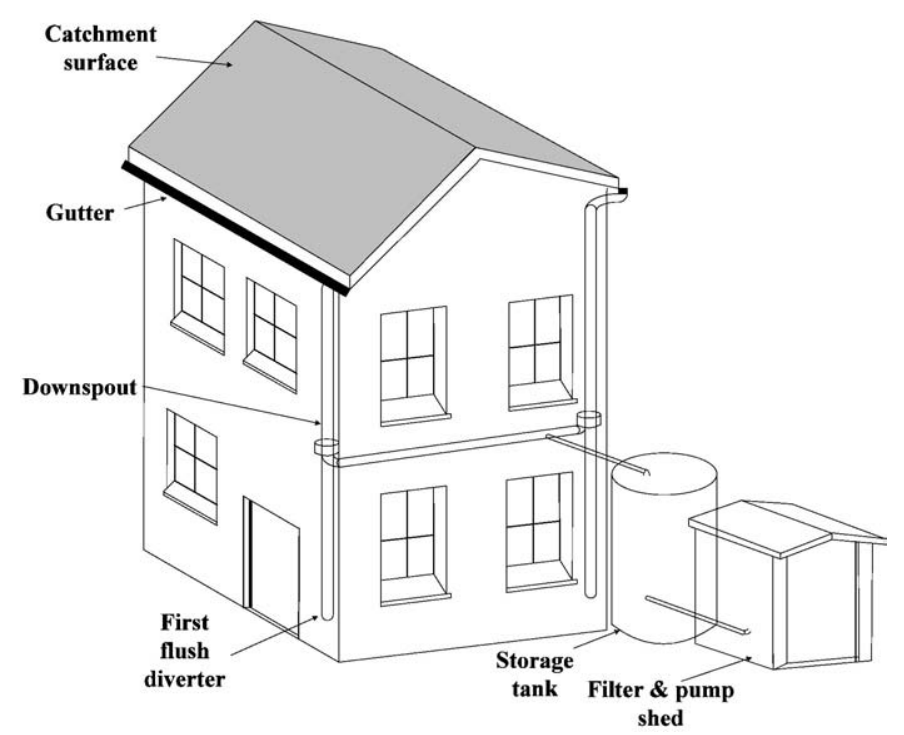

Fig. 3. A typical roof rainwater harvesting system in Ireland.

cautiously as flakes of paint or coat may wash into the tank. Generally, an unpainted and uncoated roof surface is the preferable option. A good catchment surface always contributes to a better water quality and a larger water quantity.

- Some roof catchments are built specifically for rainwater harvesting in Ireland, and as such the roof is designed with a steeper slope. But in the majority of cases, the impervious roof is constructed as normal and is effectively available for free. The roof is designed to discard water and usually has a high runoff coefficient (the ratio of the volume of water that runs off a surface to the volume that falls on to the surface [22]). A well designed roof normally has a runoff coefficient of between 0.7 and 0.9 in Ireland, with losses due to spillage, leakage, roof wetting and evaporation, all of which reduce the actual amount of rainwater that enters into the storage tank.

- The runoff delivery system - the runoff delivery system usually consists of gutters and downpipes that deliver rainwater from the roof of the house to the storage tank. Galvanised steel, stainless steel, fibreglass and plastic are the most common materials used for gutters and downpipes in Ireland. The gutters are generally suspended from the eaves and sloped towards the downpipes. Semi-circular gutters have been recognised as the most efficient at conveying water. In general, at least $1 \mathrm{~cm}^{2}$ of gutter cross-sectional area for every $1 \mathrm{~m}^{2}$ of roof area is the guide for gutter size [22]. The gutter must be designed to an appropriate size in order to discharge water to the storage tank without any overflow and this is particularly important in Ireland. Splash-guards are commonly used to prevent water overflow and spillage from the gutter. Cleaning devices, like a self-cleaning screen or guttersnipe, are often required for preventing leaves, insects and other debris entering into the storage tank. The cross-sectional area of downpipes is sometimes smaller than those of gutters as the downpipes are normally vertically positioned and, therefore, water will flow quicker through them than through a gutter. Regular gutter and downpipe maintenance and cleaning are essential to ensure they work effectively. A well designed and maintained runoff delivery system is capable of diverting over $90 \%$ of all rainwater runoff into the storage tank. However, the realistic collection efficiency is usually between $80 \%$ and $90 \%$. The conventional metal or plastic gutter and downpipe typically cost between $5 \%$ and $15 \%$ of the total rainwater harvesting system costs in Ireland, depending on local prices and conditions.

- The storage tank - the harvested rainwater is ultimately stored in a storage tank. The storage tank is generally the most expensive 
component of the system, accounting for between $50 \%$ and $70 \%$ of the total cost. Hence, it is essential to design and construct the storage tank carefully. A storage tank can be built into the house, or, generally, can be built as an individual component and located away from the house. There are a number of ways in constructing a tank with respect to its material, shape and size. Cement-brick, metal, plain-cement concrete and reinforced-cement concrete are the most commonly used materials in Ireland. A tank constructed from these materials is generally watertight, durable, and affordable and the stored water is minimally contaminated. The selection of storage tank shape depends on whether the tank is located aboveground or underground. A rectangle and square tank are used if the tank is located above ground as they are easier to construct. A tank must be cylindrical or hemispherical in shape when it is located underground, as these shapes have the advantage of resisting the substantial pressure exerted on the tank wall by soil when the tank is empty. It is critical to size the storage tank appropriately. An oversized tank may only be cycled rarely, and therefore the quality of the stored rainwater may be reduced. The expenditure on the storage tank is also higher than necessary. An undersized tank may be filled and emptied very often and could lead to insufficient water supply for the house. Tank sizes between 40001 to 16,0001 are reasonable for most Irish houses, with the size depending on the roof area available, the level of rainfall and the number of occupants in the house. Storage tanks may be designed towards the larger scale than required in Ireland because of the great quantities of rainfall available.

Storage tanks can be separated in two categories dependent on where they are placed [23]: aboveground tank and underground tank.

- An aboveground tank allows the easy detection of cracks and leaks, and water can be extracted via gravity especially when the tank is purposely raised off the ground. The aboveground tank usually costs less than the underground tank [20]. It is also easy to drain water completely for cleaning. However, the aboveground tank takes up space and requires anchoring to the ground especially with the windy Irish climate.

- An underground tank is good at preventing light penetration, keeping stored water constantly cool, and also saving on space. However the main downsides are it is difficult to extract the stored water (a pump has to be used), it is difficult to detect cracks or any problems, and there is also a possibility of contamination from groundwater and floodwater. Another downside is that the excavation costs may not be affordable for many Irish householders.

\subsubsection{Domestic harvested rainwater quality}

Good quality rainwater is likely to be harvested and stored if the DRWH system is designed well, and is operated and maintained efficiently. The quality of domestic rooftop-harvested rainwater is mainly dependent on the local air quality and roof cleanliness. The air quality remains generally good in Ireland and the harvested rainwater is usually free from physical and chemical contaminants. The significantly increasing emissions from the transport sector could be the greatest threat to the quality of harvested rainwater in large cities in Ireland. The roof is the most direct contamination path in rainwater harvesting. Particles, micro-organisms, heavy metals and organic substances, accumulated on the roofs, can greatly affect the harvested rainwater quality. It is very important to clean the roof regularly to remove dust and debris. Most importantly, the first few millimeters of dirty rainfall runoff should be diverted away from the tank to avoid contamination. Therefore the rainwater is only harvested after the roof has been washed off [24]. The storage tank should be also cleaned periodically, as some of the particles can settle in the storage tank, especially when the stored water is cycled rarely. The storage tank should be also well covered to prevent insects using it as a breeding place. Bacteria, viruses and protozoa may originate from faecal pollution by birds and mammals on the roof and storage tank [25]. The presence of bacteria and pathogens suggest that the harvested rainwater is generally not suitable for drinking. These bacteria and pathogens will gradually die off during the first several days of storage if the storage tank can avoid both light and organic matter [22]. The three bacterial indicators (coliforms, E. coli and enterococci) are commonly detected in the majority of harvested rainwater [26].

\subsubsection{Treatment of domestic harvested rainwater}

Harvested rainwater must be treated to improve its quality unless it is primarily utilised for watering gardens. Harvested rainwater is not recommended for drinking as the water quality from the public supply is high in Ireland. The simple treatment of rainwater can improve the quality significantly while the treatment to make the water potable is very sophisticated and costly. There are several cheap domestic rainwater treatments which can generally ensure that the harvested rainwater is of a sufficient quality. These are as follows:

- Disinfection - disinfection can be applied to the harvested rainwater to improve its microbiological quality [24]. Chlorination is the most common and easily applicable practice. Chlorine is applied for the deactivation of most micro-organisms and is also reasonably cheap. Chlorination is generally applied after the harvested rainwater has been removed from the storage tank, as chlorine may react with organic matter to form undesirable by-products which can settle to the bottom of the storage tank. Chlorination should meet the level of $0.4-0.5 \mathrm{mg} / \mathrm{l}$ free chlorine [26], which is considered to be effective. This can be done by applying chlorine tablets or chlorine solution. Some parasitic species have shown resistance to low doses of chlorine which is its main limitation.

- Slow sand filtration - slow sand filtration is a cheap method to improve the bacteriological quality of harvested water. Slow sand filtration is a biological treatment process rather than a physical filtration process [26]. The filter is constructed carefully by using graded sand layers that have the coarsest fraction on top and finest at the base. A constant flow of water through the filter is essential for it to be effective. Effective slow sand filtration can produce water with a very low nutrient level. This method could be well suited for houses in Ireland as there is a high frequency of rain. The main limitation of slow sand filtration is that the micro-organisms can be only reduced rather than completely cleared in the treated rainwater.

- Pasteurisation - pasteurisation is achieved by combining ultraviolet radiation and the heat from solar energy. This technique is a reliable and low-cost treatment method. The harvested water can be pasteurised by placing it in plastic bottles or bags. The method works most effectively when water temperature reaches at least $50^{\circ}$ and the water is fully oxygenated. This treatment is very effective against E. coli and other pathogenic bacteria. However the technique is limited when the concentration of suspended solids is more than $10 \mathrm{mg} / \mathrm{l}[26]$.

Multiple water treatment methods may be necessary in some cases as one treatment method may be insufficient to improve the rainwater quality for a specific requirement, e.g. bathing. However, the simplest treatment method should be chosen if low-quality harvested water is adequate for applications such as toilet flushing or garden watering. The costs will not be justified if any complex treatment method is utilised.

The harvested rainwater cannot be used for drinking after simple treatments. If the harvested water is subjected to the drinking water standard, some intensive treatments have to be taken. The coupling of a membrane filtration system and a disinfection system are commonly used for intensive treatment. If a judicious choice of the cut-off of the membranes is used, the obtained treated rainwater maybe drinkable as it contains very little viruses and bacteria. However, boiling may be needed before drinking if the size of viruses 
or bacteria existed in the treated rainwater is large. The cost of this treatment is relatively high and filters may require a lot of maintenance.

\subsubsection{Benefits of a domestic rainwater harvesting system}

There are several benefits of using a domestic rainwater harvesting system in Ireland. These are:

1) The treated rainwater is consumed at, or near, the point of production. This reduces the possibility of contamination during delivery, and also lowers the publicly-supplied running costs.

2) The significant amount of water demand from the public supply could be replaced through the extensive adoption of rainwater harvesting systems.

3) The rainwater harvesting systems can be flexibly installed in both new and existing houses.

4) The cost of operation and maintenance is generally low, since lowcost simple water treatment is sufficient as the physical, chemical and biological properties are quite acceptable if the harvested water is for non-potable purposes.

5) The house can be nearly water self-sufficient when the public water supply is interrupted. The rainwater harvesting systems can be regarded as water preventative systems which function to control water quantity and potentially reduce the risk of flooding in Ireland.

\subsubsection{Cost of a domestic rainwater harvesting system}

The cost of a DRWH system varies greatly and is mainly dependent upon the volume of storage tank required. The size of roof area, rainfall level and number of occupants are the parameters for choosing the volume of a storage tank. An underground storage tank system is also generally more expensive than an aboveground system for the same storage tank size. The cost of a rainwater harvesting system is still relatively expensive in Ireland. In 2009, the general costs for DRWH systems ranged from $€ 1,500$ to $€ 4,000$ with storage tank sizes between $1500 \mathrm{l}$ and $10,000 \mathrm{l}$. The operation cost is normally small as the electricity consumption is very little (less than $1 \mathrm{kWh}$ a day). The payback period for a DRWH system would be between 7 and 20 years in Ireland when the current UK publiclysupplied volumetric water charge is taken into account. However, with increasing water and energy costs, the payback period for a DRWH system could be a lot less than this. There is currently no government grant available for the installation of a DRWH system in Ireland. The payback period could be further reduced if an incentive grant is provided to householders in Ireland. Kingspan (Co. Monaghan, Ireland), JFC (Co. Galway, Ireland), Rainman (Co. Westmeath, Ireland) and RainHarvesting Ireland (Coleraine, UK) are the primary companies providing DRWH systems in Ireland.

\subsection{Domestic greywater treatment system}

\subsubsection{Introduction}

GW is wastewater collected from washing operations. As such, sources include showers, sinks, bath tubs, washing machines, kitchen sinks and dishwashers, but specifically exclude blackwater sources (toilet, bidets and urinals). GW generally makes up 50\% to $80 \%$ of wastewater generated in a domestic house in Ireland [27]. The use of GW can represent the largest potential source of water savings in a domestic house as its reuse contributes to preserve high-quality publicly-supplied water as well as reducing the overall costs and lessening environment pollutants. GW is of lower quality than harvested rainwater, as it contains a large proportion of the dissolved contaminants from detergent or soap products. GW is produced more regularly, and can be readily reused for domestic applications. Treated GW is mostly utilised for low-quality water applications such as toilet flushing, garden watering and car washing. A complicated treatment process can improve GW quality to make it suitable for use in washing machines and baths. However, the kind of treatments required may result in greater energy consumption and may be not economically viable. A typical domestic GW treatment system in Ireland is shown in Fig. 4.

\subsubsection{Characteristic of greywater}

The quality of GW varies from source to source. It depends on the quality of the water supply, the type of distribution system and the activities of occupants in the house. The quality of GW can be measured using physical and chemical parameters. The physical parameters are temperature, colour, turbidity and content of suspended solids [28]. The unfavourably high temperature of GW due to the use of warm water for personal hygiene can cause problems as it favours microbial growth. The chemical parameters are biological oxygen demand (BOD), chemical oxygen demand (COD), and the concentration of nutrients nitrates $(\mathrm{N})$ and phosphates $(\mathrm{P})$. The level of COD and BOD can indicate the risk of oxygen depletion due to degradation of organic matter during transport and storing [28]. The important fact is that significant chemical changes in GW may take place over only a few hours as the dissolved oxygen is depleted. It is essential to use an appropriately sized storage tank as the characteristic of the fresh GW can differ substantially compared with stored GW. Stored GW should be cycled very frequently. According to research, it has been shown that total coliform and faecal coliform count can increase from $10^{0}-10^{5} / 100 \mathrm{ml}$ to above $10^{5} / 100 \mathrm{ml}$ within $48 \mathrm{~h}$ in stored GW [27].

\subsubsection{Greywater treatment technologies}

Several GW treatment technologies have been developed. The followings are the most commonly used GW treatment technologies for domestic use:

- Basic two-stage systems - coarse filtration along with disinfection is the most commonly used technology. The coarse filter usually

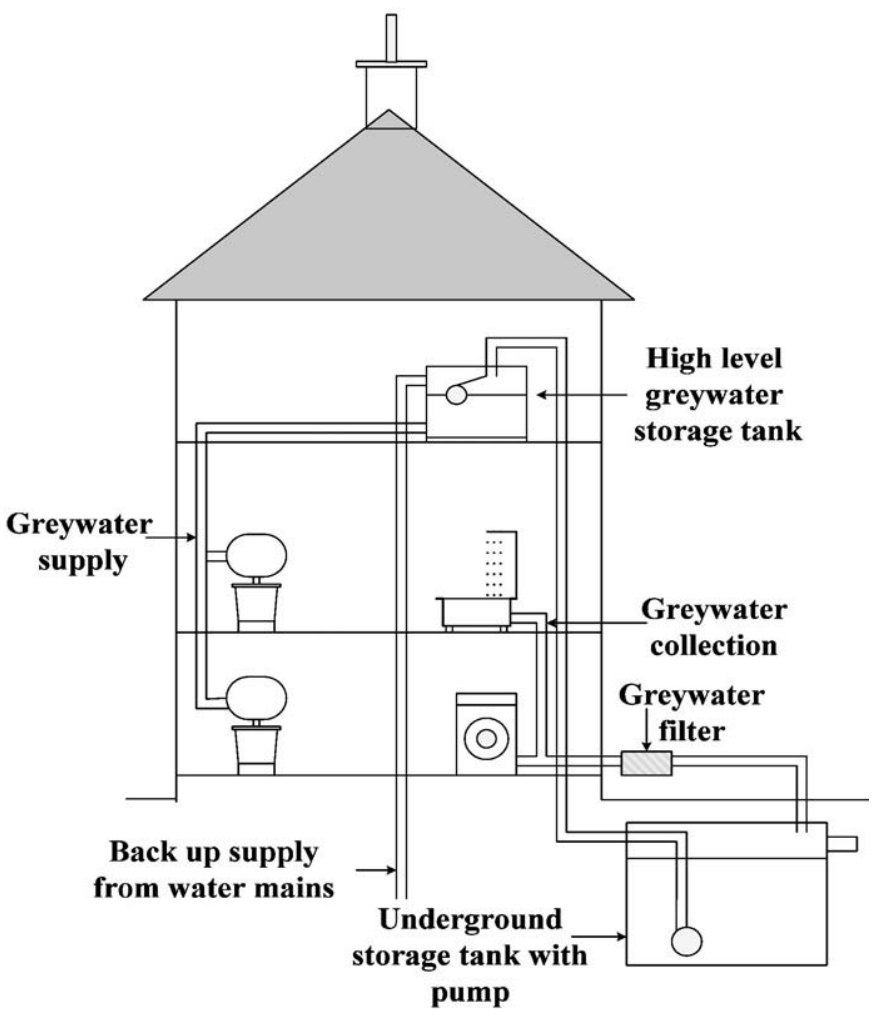

Fig. 4. A typical domestic greywater treatment system in Ireland. 
comprises a metal strainer, working as a barrier to large suspended particles and effectively removing organic pollutant. GW should be substantially cleared after filtration. Disinfection is achieved using either chlorine or bromine. These chemicals are dispensed in slow release blocks or by dosing a liquid solution. This two-stage process employs a short residence time so that the chemical nature of the GW remains unaltered and only minimal treatment is required $[29,30]$. Even though the quality of the treated GW makes it safe for reuse, it only meets the less stringent reuse standard akin to those for bathing water. The organic load and turbidity still remain high in the treated GW, as the effectiveness of the chemical disinfection process is limited. The two-stage system can suffer periodic failure of the disinfection process such that coliform levels occasionally become very high. Also the disinfectant by-products generated may have lower disinfectant capability and adversely affect human health.

- Physical process systems - a physical process system comprises mainly depth filtration, invariably based on sand, and/or membranes. Physical processes are able to achieve substantial clarification of water, membrane systems in particular. Membrane systems offer a permanent barrier to suspended particles greater than the size of membrane material, which range from $0.5 \mu \mathrm{m}$ for microfiltration membranes down to molecular dimensions for reverse osmosis [29]. The treated GW generally has better quality than that from the two-stage system. However, the energy demand for the membrane system is significantly higher than that for depth filters. Cleaning must be done frequently, otherwise fouling of the membrane surface by pollutant species can increase the hydraulic resistance of the membrane, and more energy is required for membrane permeation and/or decreasing the permeate flux. The residence time has been identified as being a major cause of concern. The GW can become anaerobic over an extended time period, and this results in the generation of organic components which are less readily rejected by the membrane.

\subsubsection{Costs of a domestic greywater treatment system}

GW treatment systems are currently not very popular in Ireland due to their high cost and the present lack of water charges. The cost of a GW treatment system varies depending on the water application and the type of system used. A substantial financial saving can be generated if a simple system is used to supply treated GW for largevolume water applications such as garden irrigation and toilet flushing. In contrast, if an expensive complex system is used for toilet flushing only, it is highly unlikely to be economically viable. A typical GW treatment system has capital and installation costs between $€ 2700$ and $€ 3400$ in Ireland. The operation costs for the chemicals required, energy for treatment and pumping, and maintenance also need to be considered. The payback period varies dependent on the volume of water used and potential volumetric charges on water supply and wastewater treatment in Ireland. Taking UK domestic water charges and the current domestic water volumetric usage in Ireland, the typical payback period will be between 20 and 35 years for a system used for toilet flushing only. However, if the system supplies water for outdoor applications like garden irrigation, water savings could be significantly higher and the payback period could be a lot shorter. Water charges, once reintroduced, tend to increase year by year, and hence the payback period will be further decreased. There is also no grant available to encourage householders to install domestic GW treatment systems in Ireland. Rainharvesting Ireland (Coleraine, UK) and Kingspan (Co. Monaghan, Ireland) are the leading companies providing domestic GW treatment systems.

\section{Potential water savings by using domestic water systems in Irish homes}

The optimised integration of DRWH systems and GW treatment systems will be expected to result up to a $94 \%$ water savings on public water supply in Ireland. Only $6 \%$ of domestic water is for potable use. The rest of the domestic water could be supplied from domestic water systems once they are properly installed. Treated GW is generated very frequently, but it usually has a lower quality than harvested rainwater and is not recommended to be stored for a long period of time. Treated greywater is most appropriate for water applications that are frequently used and require low-quality water. Toilet flushing is the best application. The $27 \%$ of domestic water used for toilet flushing could be entirely replaced by treated GW. The $12 \%$ of water that is used for "other applications" such as garden watering and car washing could also be replaced by treated GW. If the two systems work together, the harvested rainwater will be generally used for higher-water-quality-required applications such as showers and baths, washing machines and dishwashers. The high average rainfall available in Ireland makes the target of replacing 55\% of publiclysupplied-water by harvested rainwater realistic. The used rainwater can be treated the same as the general GW for lower-water-quality applications. The harvested rainwater can be also used for toilet flushing and/or garden watering if the DRWH system works alone. The storage tank may have to be sized somewhat larger to satisfy all the water demand in the house. The potential water saving is estimated to be between $30 \%$ and $90 \%$ in an Irish house, with the possibility of obtaining all of the $94 \%$ of domestic water used for nonpotable applications from DRWH and GW treatment systems. However, the techniques for integrating DRWH and GW treatment systems, and the costs of purchasing and installing these systems, can deter some Irish householders.

\section{Conclusion}

A potential water shortage in Ireland will be a key issue for its sustainable development in the future. DRWH and GW treatment systems have been used in different parts of the country, but their use is not yet widespread. Harvested rainwater and treated GW can play a major role in substituting and/or supplementing Ireland's water supply from the centralised water supply facilities. The potential of potable water savings can be substantial by using these water systems either separately or together. The unique Irish climate and the large water consumption per capita per day could result in roughly $94 \%$ of the current water supply from public water supply being substituted by harvested rainwater and treated GW if the systems are appropriately installed and operated.

The potential reintroduction of a domestic water charge may have a key impact on the adoption of domestic water systems in Ireland. Householders may be willing to utilise these water systems in order to avoid paying a large water bill. Reducing the use of publicly-supplied water through DRWH and GW treatment systems will also cut down the cost of providing a centralised water supply by the Irish government. Therefore, incentives and government support are essential mechanisms to encourage Irish householders to apply these water systems.

\section{Acknowledgement}

The first author would like to express his appreciation to the Irish Research Council for Science, Engineering and Technology for its support during the research study period.

\section{References}

[1] H. Furumai, Rainwater and reclaimed wastewater for sustainable urban water use, Physics and Chemistry of the Earth, Parts A/B/C 33 (5) (2008) 340-346.

[2] Water supply project - Dublin region, 2008, Veolia Water \& RPS Group.

[3] Drinking Water Quality in EPA Viewpoints, 2006, Environmental Protection Agency.

[4] International Comparisons of Domestic Per Capita Consumption in Water and the Environment, 2008, Environment Agency. 
[5] Cullen Publishes €5 Billion Water Services Investment Programme, 2004, National Development Plan.

[6] Public Capital Programme 2006. 2006, Government of Ireland

[7] S. Scott, Application of polluter pays principle in Ireland, Water Framework Directive Implementation, International water association and engineers Ireland, 2007.

[8] The Problems of Water Stress, 2006, European Environmental Agency.

[9] Gormley, J., €300 Million Water Conservation Investment Plan, H.L.G. Department of the Environment, Editor. 2009: Dublin.

[10] Environmental Performance Reviews - Ireland, 2009, Organisation for Economic Co-operation and Development.

[11] Agency, E.P., The Provision and Quality of Drinking Water in Ireland - A Report for the Years 2007-2008. 2009.

[12] Water supply in Ireland. [cited 201001 24]; Available from: http://www. citizensinformation.ie/categories/environment/water-services/water_supply.

[13] C.I. Board, Water Supply in Ireland, 2009.

[14] F. Sheahan, A. Kerr, P. Melia, All Homes Face $€ 175$ Water Bill in Greens' new Deal in Irish Independent, 2009.

[15] Your Water and Sewerage Bill 2009-10. 2009, Ofwat (The Water Services Regulation Authority).

[16] Ireland at Risk - Water, The Irish Academy of Engineering, 2007.

[17] P.Connell, D.D.Pringle, Population Aging in Ireland Projections 2002-2021, 2004, National Council on Ageing and Older People.

[18] Number of Private Households, Persons in Private Households and Average Number of Persons per Private Households in each Province, County and City 2006, Central Statistics Office, Ireland, 2006.

[19] F.O.Rourke, F.Boyle, A.Reynolds, Renewable energy resources and technologies applicable to Ireland, Renewable and Sustainable Energy Reviews 13 (8) (2009) 1975-1984.
[20] F.A. Abdulla, A.W. Al-Shareef, Roof rainwater harvesting systems for household water supply in Jordan, Desalination 243 (1-3) (2009) 195-207.

[21] Service, T.I.M. Rainfall. [cited 200910 19]; Available from: http://www.met.ie/ climate/rainfall.asp.

[22] J. Gould, E. Nissen-Petersen, Rainwater Catchment Systems for Domestic Supply, Intermediate Technology Publications, 1999.

[23] M. Sturm, et al., Rainwater harvesting as an alternative water resource in rural sites in central northern Namibia, Physics and Chemistry of the Earth, Parts A/B/C 34 (13-16) (2009) 776-785.

[24] E. Sazakli, A. Alexopoulos, M. Leotsinidis, Rainwater harvesting, quality assessment and utilization in Kefalonia Island, Greece, Water Research 41 (9) (2007) 2039-2047.

[25] J.M. Mwenge Kahinda, A.E. Taigbenu, J.R. Boroto, Domestic rainwater harvesting to improve water supply in rural South Africa, Physics and Chemistry of the Earth Parts A/B/C 32 (15-18) (2007) 1050-1057.

[26] B. Helmreich, H. Horn, Opportunities in rainwater harvesting, Desalination 248 (1-3) (2009) 118-124.

[27] O.R. Al-Jayyousi, Greywater reuse: towards sustainable water management, Desalination 156 (1-3) (2003) 181-192.

[28] E. Eriksson, et al., Characteristics of grey wastewater, Urban Water 4 (1) (2002) 85-104.

[29] B. Jefferson, et al., Technologies for domestic wastewater recycling, Urban Water 1 (4) (2000) 285-292.

[30] J.G. March, M. Gual, Studies on chlorination of greywater, Desalination 249 (1) (2009) 317-322. 